\title{
PREDICTORS OF DRIVE FOR MUSCULARITY AMONG ADOLESCENT MALES
}

\author{
Jelena MUSTAPIC ${ }^{1}$, Darko MARCINKO르, Petra VARGEK ${ }^{3}$ \\ ${ }^{1}$ Center for Diagnostics, Prison System Directorate \\ Ministry of Justice of the Republic of Croatia \\ Dr. Luje Naletilica 1, 10000 Zagreb, Croatia \\ e-mail: jmustapic@warpmail.net \\ ${ }^{2}$ Department of Psychiatry, University Hospital Center Zagreb \\ Kispaticeva 12, 10000 Zagreb, Croatia \\ ${ }^{3}$ Department of Psychiatry, County Hospital Cakovec \\ Ulica Ivana Gorana Kovacica 1E, 40000 Cakovec, Croatia
}

\begin{abstract}
The aim of the current study was to explore body satisfaction, peer pressure and body shame as predictors of drive for muscularity among adolescent males. A total of 213 adolescent males completed the questionnaires assessing body satisfaction, peer pressure, body shame and drive for muscularity. The results indicated that drive for muscularity was predicted by body shame and body satisfaction. Participants' BMI, age, and experienced level of peer pressure did not play a role as significant predictors of drive for muscularity. Future longitudinal research should focus on clarifying the role of body shame in the development of drive for muscularity and extreme body changing behaviors.
\end{abstract}

Key words: adolescent males, drive for muscularity, body shame, body satisfaction, peer pressure

\section{Introduction}

Body dissatisfaction is defined as a negative evaluation of one's figure, body part, muscularity/tone, weight or size (Grogan, 2008). Traditionally, body dissatisfaction has been characterized as a predominantly female issue. However, recent research has shown an increasing recognition of the body dissatisfaction among adolescent boys (Presnell, Bearman, \& Stice, 2004). Evidence suggests that as boys enter adolescence they begin to experience higher levels of body dissatisfaction (Schur, Sanders, \& Steiner, 2000). Some estimates indicate that $30-75 \%$ of adolescent boys are dissatisfied with their bodies (Markey \& Markey, 2005). The data collected from the study done by Kostanski, Fisher and Gullone (2004) showed that both the underweight and overweight adolescent boys reported higher levels of body dissatisfaction compared to normal weight boys. The prevalence of male body dissatisfaction has increased to the extent that dissatisfaction with overall body size and particular upper body parts (i.e., shoulders, arms, chest) has been described as "normative" (Dakanalis \& Riva, 2013).

McCabe et al. (2012) stated that male body concerns are qualitatively different from females'. While the majority of females desired thinner physique, males often express their body dissatisfaction in terms of muscle tone

DOI: $10.21909 /$ sp.2015.03.694 
and size (Smolak, Murnen, \& Thompson, 2005). Grossbard, Neighbors and Larimer (2011) found that males' ideal body figure was significantly more muscular than their current body figure. Males also overestimated the level of muscularity that women find attractive in men, which was consistent with past research that suggests that males, unlike females, typically strive to increase muscle mass rather than lose weight. Furthermore, growing amount of research demonstrates the importance of being muscular in both adolescent males and adult men (Jones \& Crawford, 2005). In contrast to the female thin ideal, the ideal body for males is both lean and muscular (Frederick et al., 2007), which presents an equally unattainable standard to average male. McCreary and Sasse (2000) proposed the construct drive for muscularity to represent the males' desire or need to become more muscular. Labeled as a drive, it suggests that individuals may have an aroused state of intrapersonal tension that is generated from perceptions of insufficient musculature, which results in actions to reduce this tension, muscular discrepancies and increases behaviors that are indicative of muscle building to ascertain these ideal physiques (Bergeron \& Tylka, 2007). One of the main reasons muscularity is so important to men and boys is that it is associated with perceptions of their masculinity; in other words, the more muscular a man or boy is, the more masculine he is (McCreary, Saucier, \& Courtenay, 2005). Another study has shown that males who adopted more masculine gender roles and stereotypical male behaviors experienced greater drive for muscularity (Swami \& Voracek, 2012). Adolescent boys may experience perceived social pressure to conform to the muscular ideal in similar ways as ado- lescent girls may feel pressured to conform to the thin ideal (Smolak et al., 2005). Among adolescent boys, a higher drive for muscularity is associated with lower self-esteem and more depressive symptoms (McCreary $\&$ Sasse, 2000). The drive for muscularity may lead to potentially harmful behaviors such as overeating, rigid dietary regimens and inflexible rules regarding the type and amount of food to be consumed, exercise dependence, use of anabolic-androgenic steroids and dietary supplements to increase muscle mass or stamina for weight lifting (Chittester \& Hausenblas, 2009; Litt \& Dodge, 2008 , Ricciardelli \& McCabe, 2004). As a consequence of high drive for muscularity some adolescent boys and adult men can develop muscle dysmorphia, which is described as an excessive and pathological preoccupation with muscularity and leanness (Pope et al., 2005).

Peers are especially important component of adolescents' social context and represent a powerful influence on body-related behaviors (Keery, van der Berg, \& Thompson, 2004). For males, receiving direct and indirect feedback from peers and comparing oneself to peers may be more powerful in affecting body satisfaction than comparing oneself to images in the media. McCabe and McGreevy (2011) found that peers, especially close friends, had a greater influence on muscle building than messages from the media about what is attractive. Adolescent males who do not fit the ideal body image felt pressure from their peers who had a more developed muscular body figure (Xu et al., 2010; Stout \& Frame, 2004). Furthermore, higher frequency of negative peers comments was associated with lower self-esteem and lower body satisfaction among male students (Nowell \& Ricciardelli, 2008). 
When individuals are constantly presented with idealized body images and often unattainable standards of beauty and attractiveness, they may come to view themselves as objects to be admired and used by others, rather than as individuals with unique interests, abilities and drives (Vandenbosch \& Eggermont, 2013). Body shame is a result of one's body not meeting what one perceives to be the ideal body type for a particular culture (Tylka \& Sabik, 2010). Although similar to body dissatisfaction, because both body shame and body dissatisfaction encompass one's negative thoughts and feelings toward their body, body shame has a wider meaning. Body shame is not only characterized by negative feelings about the body, but about the self in general (McKinley \& Hyde, 1997). To date, very few researchers have examined relationship of body shame and body related consequences, especially on male population. Grieve and Helmick (2008) found that males who scored higher on objectification measures, one of which measured the level of experienced body shame, demonstrate higher incidences of drive for muscularity. Body shame was one of the variables most constantly related to drive for muscularity (Edwards, Tod, \& Molnar, 2014). Higher level of body shame was correlated with higher level of masculine body image distress and drive for muscularity (Greentree \& Lewis, 2011) Another study reported that body shame was a unique predictor of eating pathology among males (Doran \& Lewis, 2012).

Drive for muscularity has not been as widely studied as its female counterpart, drive for thinness. More knowledge is needed to explain the development of drive for muscularity in both adolescent males and adult men. In order to contribute to better understanding of the concept of drive for muscularity, the current study's objective was to examine the relationship between body dissatisfaction, peer pressure, body shame and drive for muscularity in adolescent males.

Method
Participants
The study participants were 213 male stu-
dents from three different secondary schools
in Zagreb. Students attended first, second
and third year of high school. The sample
ranged in age from 14 to 18 years $(M=15.83$;
$S D=1.064)$. The students were from middle-
class backgrounds as inferred on the basis
of school district characteristics and student-
reported parental education levels.

\section{Measures}

Four questionnaires including Body Shape Satisfaction Scale, Peer Pressure Questionnaire, Body Shame subscale of the Objectified Body Consciousness Scale, and Drive for Muscularity Scale were used.

Body satisfaction, consisting of 10 items, was assessed with a modified version of the Body Shape Satisfaction Scale (Pingitore et al., 1997). Ten items assessed satisfaction with each of ten body features (height, weight, shape, waist, shoulders, hips, thighs, stomach, face, body build and shoulders). For each item there were five Likert response categories ranging from 1 (very dissatisfied) to 5 (very satisfied) and responses were summed. Scores ranged from 10 to 50, and higher scores indicated greater dissatisfaction. The alpha coefficient for this sample was .93 . 
Peer pressure was assessed by the 22-item Peer Pressure Questionnaire (LebedinaManzoni, Lothar, \& Ricijas, 2008), designed to measure perceived peer pressure. Items are rated on a 5-point Likert scale ranging from 1 (strongly disagree) to 5 (strongly agree) with higher scores indicating a higher level of perceived peer pressure. The alpha coefficient in the present sample was .87.

The Body Shame subscale of the Objectified Body Consciousness Scale (BS-OBCS; McKinley \& Hyde, 1996) consisted of 8 items and measured shame experienced when internalized cultural body standards are not met. Items are rated on a 6-point Likert scale ranging from 1 (strongly disagree) to 6 (strongly agree) with higher scores indicating a higher level of body shame. The alpha internal consistency reliability in the present sample was .86.

The Drive for Muscularity Scale is a 15item scale that measures individual's drive, or desire, for a more muscular body (McCreary \& Sasse, 2000). Participants indicate how each of them reflects their own behaviors and attitudes using a 6-point Likerttype scale ranging from 1 (always) to 6 (never) and items are reverse scored. In our analysis we used the average overall score. For current sample the Cronbach's alpha coefficient was 0.89 .

Socio-demographic data form was prepared considering the objectives of the study in order to obtain information about participants' age, parental education level and current residence.

Body mass index (BMI) was calculated using self-reported information about weight and height of every participant. After BMI was calculated, the BMI number was plotted on the BMI-for-age growth charts to obtain a percentile ranking that indicated the rela- tive position of the adolescent's BMI number among peers of the same sex and age. The weight status categories used were underweight (less than the 5th percentile), healthy/normal weight (5th percentile to less than the 85 th percentile), overweight (85th to less than the 95th percentile) and obese (equal to or greater than the 95th percentile).

\section{Procedure}

Following approval by the school Principals, the questionnaires were administered to groups of students during regular school hours. Passive parental consent was obtained for all participants. Prior to administering the questionnaires students signed an informed consent. Those students whose parents refused to permit them to participate were not given questionnaires. Teachers were present throughout the testing, and research assistant was available to answer questions. Students' participation was voluntary. Completion of the questionnaires took approximately one school hour. All questionnaires were submitted to the research assistant without the name of the participant.

\section{Results}

Descriptive statistics for all study variables are presented in Table 1.

Pearson coefficient was used to conduct the correlation analysis between the drive for muscularity and other variables. There was a significant positive correlation between the drive for muscularity and perceived peer pressure $(r=0.254, p<0.001)$. A significant positive correlation was observed between the drive for muscularity and body shape satisfaction $(r=0.375, p<0.001)$ and between the drive for muscularity and body 
shame $(r=0.278, p<0.001)$. However, there was no significant correlation between the drive for muscularity and age of participants ( $r=0.128, p=0.063)$, as well as between the drive for muscularity and their BMI ( $r=$ $-0.011, p=0.872$ ). Correlations between the drive for muscularity and other variables are presented in Table 2.

Multiple regression analysis was carried out to determine the connection between the drive for muscularity as dependent variable and age, BMI, peer pressure, body shape satisfaction and body shame as independent variables. Preliminary analyses were conducted to ensure no violation of the assumptions of normality, linearity, and homoscedasticity. After examining the Normal Prob- ability Plot of the Regression Standardized Residual and the Scatterplot such violations were not observed. Results showed that the regression was significant $\left(R=0.440, R^{2}=\right.$ $0.194, R_{\text {adiusted }}^{2}=0.174, F(5,211)=9.903, p<$ $0.001)$. Of the variables entered into this model, the strongest predictor of the drive for muscularity among adolescent males was body shame, followed by body shape satisfaction. Thus, our findings indicated that higher level of experienced body shame and increased level of body shape dissatisfaction significantly predicted adolescent males' drive for muscularity. Correlation of age, BMI, peer pressure, body shape satisfaction and body shame regression scores with the drive for muscularity are presented in Table 3.

Table 1 Descriptive statistics for study variables

\begin{tabular}{lrccc}
\hline & $M$ & $S D$ & Min & Max \\
\hline Age & 15.83 & 1.06 & 14 & 18 \\
BMI & 2.16 & 0.61 & 1 & 4 \\
Perceived peer pressure & 46.73 & 12.55 & 25 & 109 \\
Body Shape Satisfaction & 21.49 & 9.48 & 10 & 50 \\
Body Shame & 10.32 & 5.78 & 6 & 42 \\
Drive for Muscularity & 35.65 & 13.53 & 15 & 90 \\
\hline
\end{tabular}

Table 2 Correlation between drive for muscularity and other variables $(N=213)$

\begin{tabular}{lcc}
\hline Variable & $r$ & \multicolumn{1}{c}{$p$} \\
\hline Age & 0.128 & 0.063 \\
BMI & -0.011 & 0.872 \\
Peer pressure & 0.254 & $<0.001$ \\
Body shape satisfaction & 0.375 & $<0.001$ \\
Body shame & 0.278 & $<0.001$ \\
\hline
\end{tabular}


Table 3 Correlation of age, BMI, peer pressure, body shape satisfaction and body shame regression scores with drive for muscularity

\begin{tabular}{lrrrrrrrr}
\hline \multirow{2}{*}{ *Predictors } & \multirow{2}{*}{$B$} & \multirow{2}{*}{ SEB } & $\beta$ & $t$ & $p$ & \multicolumn{2}{c}{$\begin{array}{c}\text { Lower } \mathrm{CI} \text { for } B \\
\text { Upper }\end{array}$} \\
& & & & & & \multicolumn{1}{c}{$B}$. & \multicolumn{1}{c}{$B}$. \\
\hline Age & 1.385 & 0.807 & 0.109 & 1.716 & 0.088 & -0.206 & 2.977 \\
BMI & -1.495 & 1.436 & -0.067 & -1.042 & 0.299 & -4.326 & 1.335 \\
Perceived peer pressure & 0.125 & 0.074 & 0.116 & 1.686 & 0.093 & -0.021 & 0.272 \\
Body shape satisfaction & 0.202 & 0.099 & 0.142 & 2.035 & 0.043 & 0.006 & 0.397 \\
Body shame & 0.695 & 0.161 & 0.297 & 4.316 & 0.000 & 0.377 & 1.012 \\
\hline
\end{tabular}

*Dependent variable: Drive for muscularity

\section{Discussion}

The purpose of the present study was to examine the relationship between drive for muscularity and body satisfaction, peer pressure and body shame.

Our results showed that body shame was the strongest predictor of drive for muscularity among the variables included in our analysis. The tendency among adolescent males to experience higher level of body shame appeared to be associated with a stronger drive to attain a muscular physique. The limited available research has been consistent with our findings. Calogero and Thompson (2009) have found that males who attend more to their physical appearance in an effort to avoid the negative consequences of failing to meet current ideal body standards experienced higher levels of body shame. The objectification theory (Fredrickson \& Roberts, 1997) could offer explanation of rise of body shame among men. Objectification theory proposes that selfobjectification leads to increased experiences of shame and, in particular, shame about one's body. Although the aforementioned theory was developed primarily to explain the process of objectification of females' bodies, recent research shows that this theoretical framework is becoming increasingly relevant to males (Frederick et al., 2007a; Strelan \& Hargreaves, 2005). Males' bodies are exposed to media representations of powerful and muscular male bodies (e.g., Frederick, Fessler, \& Haselton, 2005) and scrutinized by women or by other men. Tiggemann and Kuring (2004) have shown that self-objectification led to self-surveillance and, in turn, body shame among both women and men.

Based on our results, body shape satisfaction was the secondary significant predictor of drive for muscularity among adolescent males. Those adolescents who experienced higher body dissatisfaction had a stronger drive for muscularity. Frederick et al. (2007) reported that failure to achieve a lean and muscular build, which is a prominent characteristic of masculinity for many men, led to body dissatisfaction. Furthermore, men's ratings of their current and ideal muscularity were associated with endorse- 
ment of the male role, and many men desired increased muscularity for reasons related to increased dominance and attractiveness to women. In line with our findings, Jones, Bain and King (2008) found that $66 \%$ of the adolescent males endorsed body dissatisfaction, including $38 \%$ that wanted to lose body fat and $28 \%$ that wanted to gain weight. Neumark-Sztainer et al. (2006) found that 24\% of adolescent boys reported low body satisfaction and unhealthy weight control behaviors, including excessive exercising and binge eating. Men who are dissatisfied with their body shape report higher levels of depression, eating pathology, and use of performance- enhancing substances, as well as lower self-esteem (Olivardia et al., 2004).

Perceived pressure to be muscular from peers plays an important role in adolescent boys body image attitudes and behaviors aimed at changing their appearance (Thompson \& Cafri, 2007). Adolescent males who received more messages from their friends regarding increasing muscles reported more attempts to change body shape and size (Eisenberg \& Neumark-Sztainer, 2010; Stout \& Frame, 2004). In our study, we found that peer pressure was positively correlated to drive for muscularity. However, perceived peer pressure did not predict drive for muscularity among adolescent males in our sample. It is possible that the used peer pressure questionnaire was not specific enough; appearance-related peer pressure questionnaire may be used in future research to examine more closely the source and/or type of pressure perceived among adolescent males (Stanford \& McCabe, 2005). Furthermore, it may be that the impact of peer pressure may differ between adolescents. Some adolescent boys develop body changing behaviors in association with peer pressure, while others enlist active and positive strategies to manage this without becoming dissatisfied with their appearance (Webb \& Zimmer-Gembeck, 2014). Paucity of longitudinal data limits our understanding of peer pressure, as well as other interpersonal influences on the drive for muscularity in adolescent boys. Further research would aid in clarifying this issues.

Body mass index (BMI) presents one of important variables to consider regarding weight and muscularity concerns. The long line of research shows that as BMI increases, males become more dissatisfied with their bodies (Xu et al., 2010; van den Berg et al., 2007; Presnell, Bearman, \& Stice, 2004). Other studies suggested that both underweight and overweight males are more dissatisfied with their body and expressed more body-changing concerns, including dieting and muscle-enhancing strategies (Jones \& Crawford, 2005; Furnham \& Calnan, 1998). Although the relationship between BMI and male body-image disturbance exists, several authors have found no association between BMI and drive for muscularity (Jones, Bain, \& King, 2008; McCreary, Karvinen, \& Davis, 2006). Our results supported previous claims, because participants' BMI did not play a role as significant predictor of drive for muscularity. A possible explanation for this could be the nature of the BMI itself: because it is a height-to weight ratio, it does not distinguish between weight attributable to body fat versus weight attributable to muscle (Chittester \& Hausenblas, 2009).

Contrary to our expectations, we found that age did not correlate with the increase of drive for muscularity in adolescent males. This is interesting given that Smolak, Murnen and Thompson (2005) stated the preference 
for a muscular body might peak in early adolescence. Other authors have suggested that boys may develop greater body image concerns with age due to a greater awareness of current male body ideals (Jones et al., 2008; McCabe \& Ricciardelli; 2004). Future research will need to explore this issue in more depth. A more extended age range of boys in different developmental periods and contexts should be considered.

The present study has several limitations that must be addressed. First, this study was correlational in nature; we cannot say that whether body dissatisfaction or body shame cause drive for muscularity. Longitudinal research could help clarify the role of these factors, especially the role of body shame, in the development of the drive for muscularity. Extreme body shape changing behaviors among males should also be addressed. Second, the results were based on self-report survey data, which does not ensure complete honesty from the participants. Also, like many studies before, we relied on self-reported (as opposed to measured) values of height and weight to derive participants' BMI. The use of objective (measured) BMI is recommended in future research, because several studies have found that self-reported BMI was significantly lower than measured BMI (Elgar et al., 2005; Brenner et al., 2003). Another limitation is that in current research we used only one measure of body shame. Future research should use all three measures of objectified body consciousness, which includes body surveillance scale, body shame scale and scale of appearance control beliefs. The use of more body specific measures of peer pressure should also be considered.

Received October 15, 2014

\section{References}

Bergeron, D., \& Tylka, T. L. (2007). Support for the uniqueness of body dissatisfaction from drive for muscularity among men. Body Image, 4, 288295.

Brener, N. D., McManus, T., Galuska, D. A., Lowry, R., \& Wechsler, H. (2003). Reliability and validity of self-reported height and weight among high school students. Journal of Adolescent Health, $32,281-287$.

Calogero, R. M., \& Thompson, J. K. (2009). Potential implications of the objectification of women's bodies for women's sexual satisfaction. Body Image, 6(2), 145-148.

Chittester, N. I., \& Hausenblas, H. A. (2009). Correlates of drive for muscularity: The role of anthropometric measures and psychological factors. Journal of Health Psychology, 14, 872877.

Dakanalis, A., \& Riva, G. (2013). Current considerations for eating and body-related disorders among men. In L. B. Sams, J. A. Keels (Eds.), Handbook on body image: Gender differences, sociocultural influences and health implications. Nova Science Publishers, 195-216.

Davis, C., Karvinen, K., \& McCreary, D. R. (2005). Personality correlates of a drive for muscularity in young men. Personality and Individual Differences, 39, 349-359.

Doran, J., \& Lewis, C. A. (2012). Components of shame and eating disturbance among clinical and non-clinical populations. European Eating Disorders Review, 20(4), 265-270.

Edwards, C., Tod, D., \& Molnar, G. (2014). A systematic review of the drive for muscularity research area. International Review of Sport and Exercise Psychology, 7(1), 18-41.

Eisenberg, M., \& Neumark-Sztainer, D. (2010). Friends' dieting and disordered eating behaviors among adolescents five years later: Findings from Project EAT. Journal of Adolescent Health, 47(1), 67-73.

Eisenberg, M., \& Neumark-Sztainer, D. (2008). Peer harassment and disordered eating. International Journal of Adolescent Medicine and Health, 20(2), 155-164.

Elgar, F. J., Roberts, C., Tudor-Smith, C., \& Moore, L. (2005). Validity of self-reported height and weight and predictors of bias in adolescents. Journal of Adolescent Health, 37, 371-375. 
Frederick, D. A., Fessler, D. M. T., \& Haselton, M. G. (2005). Do representations of male muscularity differ in men's and women's magazines? Body Image: An International Journal of Research, 2, 81-86.

Frederick, D. A., Buchanan, G. M., Sadeghi-Azar, L., Peplau, L. A., Haselton, M. G., Berezovskaya A., et al. (2007). Desiring the muscular ideal: Men's body satisfaction in the United States, Ukraine, and Ghana. Psychology of Men \& Masculinity, 8, 103-117.

Frederick, D. A., Forbes, G. B., Grigorian, K. E., \& Jarcho, J. M. (2007a). The UCLA Body Project I: Gender and ethnic differences in self-objectification and body satisfaction among 2,206 undergraduates. Sex Roles, 57, 317-327.

Fredrickson, B. L., \& Roberts, T. A. (1997). Objectification theory: Toward understanding women's lived experiences and mental health risks. Psychology of Women Quarterly, 21, 173-206.

Furnham, A., \& Calnan, A. (1998). Eating disturbance, self-esteem, reasons for exercising and body weight dissatisfaction in adolescent males. European Eating Disorders Review, 6, 58-72. .

Greentree, S., \& Lewis, V. (2011). Male body image and its relationship to sexual preference and homophobia. Pakistan Journal of Psychological Research, 26(2), 105-126.

Grieve, R., \& Helmick, A. (2008). The influence of men's self-objectification on the drive for muscularity: Self-esteem, body satisfaction and muscle dysmorphia. International Journal of Men's Health, 7(3), 288-298.

Grogan, S. (2008). Body image: Understanding body satisfaction in men, women, and children. New York: Routledge.

Grossbard, J. R., Neighbors, C., \& Larimer, M. E. (2011). Perceived norms for thinness and muscularity among college students: What do men and women really want? Eating Behaviors, 12(3), 192-199.

Jones, D. C., \& Crawford, J. K. (2006). The peer appearance culture during adolescence: Gender and body mass variations. Journal of Youth and Adolescence, 35(2), 243-255.

Jones, D. C., Bain, N., \& King, S. (2008). Weight and muscularity concerns as longitudinal predictors of body image among early adolescent boys: A test of the dual pathways model. Body Image, 5(2), 195-204.

Keery, H., Van den Berg, P., \& Thompson, J. K. (2004). An evaluation of the tripartite influence model of body dissatisfaction and eating distur- bance with adolescent girls. Body Image, 1, $237-$ 251.

Kostanski, M., Fisher, A., \& Gullone, E. (2004). Current conceptualization of body image dissatisfaction: Have we got it wrong? Journal of Child Psychology and Psychiatry, 45, 1317-1325.

Lebedina-Manzoni, M., Lotar, M., \& Ricijaš, N. (2008). Susceptibility to peer pressure among adolescents - the challenges of defining and measuring. Annual of Social Work, 15(3), 401-419.

Litt, D., \& Dodge, T. (2008). A longitudinal investigation of the Drive for Muscularity Scale: Predicting use of performance enhancing substances and weightlifting among males. Body Image, 5(4), 346-351.

Markey, C. N., \& Markey, P. M. (2005). Relations between body image and dieting behaviours: An exploration of gender differences. Sex Roles: A Journal of Research, 53, 519-530.

McCabe, M. P., Fuller-Tyszkiewicz, M., Mellor, D., Ricciardelli, L., Skouteris, H., \& Mussap, A. (2012). Body satisfaction among adolescents in eight different countries. Journal of Health Psychology, 7(5), 693-701.

McCabe, M. P., \& McGreevy, S. J. (2011). Role of media and peers on body change strategies among adult men: Is body size important? European Eating Disorders Review, 19, 438-446.

McKinley, N. M., \& Hyde, J. S. (1996). The objectified body consciousness scale: Development and validation. Psychology of Women Quarterly, 20, 181-215.

McCreary, D. R., Karvinen, K., \& Davis, C. (2006). The relationship between the drive for muscularity and anthropometric measures of muscularity and adiposity. Body Image, 3, 145-152.

McCreary, D. R., \& Sasse, D. K. (2000). An exploration of the drive for muscularity in adolescent boys and girls. Journal of American College Health, 48(6), 297-304.

McCreary, D. R., Saucier, D. M., \& Courtenay, W. H. (2005). The drive for muscularity and masculinity: Testing the associations among genderrole traits, behaviors, attitudes, and conflict. Psychology of Men \& Masculinity, 6(2), 83-94.

Neumark-Sztainer, D., Paxton, S. J., Hannan, P. J., Haines, J., \& Story, M. (2006). Does body satisfaction matter? (Five-year longitudinal associations between body satisfaction and health behaviors in adolescent females and males). Journal of Adolescent Health, 39, 244-251.

Nowell, C., \& Ricciardelli, A. L. (2008). Appearance-based comments, body dissatisfaction and 
drive for muscularity in males. Body Image, 5, 337-345.

Olivardia, R., Pope, H., Borowiecki, J. III, \& Cohane, G. (2004). Biceps and body image: The relationship between muscularity and self-esteem, depression, and eating disorder symptoms. Psychology of Men and Masculinity, 5, 112-120.

Pingitore, R., Spring, B., \& Garfieldt, D. (1997). Gender differences in body satisfaction. Obesity Research, 5(5), 402-409.

Pope, C. G., Pope, H. G., Menard, W., Fay, C., Olivardia, R., \& Phillips, K. A. (2005). Clinical features of muscle dysmorphia among males with body dysmorphic disorder. Body Image, 2, 395400 .

Presnell, K., Bearman, S. K., \& Stice, E. (2004). Risk factors for body dissatisfaction in adolescent boys and girls: A prospective study. International Journal of Eating Disorders, 36(4), 389. 401.

Ricciardelli, L. A., \& McCabe, M. P. (2004). A biopsychosocial model of disordered eating and the pursuit of muscularity in adolescent boys. Psychological Bulletin, 130, 179-205.

Rodgers, R. F., Ganchou, C., Franko, D. L., \& Chabrol, H. (2012). Drive for muscularity and disordered eating among French adolescent boys: A sociocultural model. Body Image, 9(3), 31823.

Schur, E. A., Sanders, M., \& Steiner, H. (2000). Body dissatisfaction and dieting in young children. International Journal of Eating Disorders, 27(1), 74-82.

Smolak, L. Murnen, S. K., \& Thompson, J. K. (2005). Sociocultural influences and muscle building in adolescent boys. Psychology of Men \& Masculinity, 6(4), 227-239.

Stanford, J., \& McCabe, M. (2005). Sociocultural influences on boys' body image and body change strategies. Body Image, 2, 105-113.

Stout, E. J., \& Frame, M. W. (2004). Body image disorder in adolescent males: Strategies for school counselors. Professional School Counseling, 8(2), 176-181.

Swami, V., \& Voracek, M. (2012). Associations among men's sexist attitudes, objectification of women, and their own drive for muscularity. Psychology of Men \& Masculinity, 14(2), 1-10.

Strelan, P., \& Hargreaves, D. (2005). Reasons for exercise and body esteem: Men's responses to self-objectification. Sex Roles, 53 (7/8), 495-503.

Thompson, J. K., \& Cafri, G. (2007). The muscular ideal: Psychological, social, and medical perspectives. Washington, DC: American Psychological Association.

Tiggemann, M., \& Kuring, J. K. (2004). The role of body objectification in disordered eating and depressed mood. British Journal of Clinical Psychology, 43, 299-311.

Tylka, T. L., \& Sabik, N. J. (2010). Integrating social comparison theory and self-esteem within objectification theory to predict women's disordered eating [Special issue]. Sex Roles, 63, 1831 .

Van den Berg, P., Paxton, S. J., Keery, H., Wall, M., Guo, J., \& Neumark-Sztainer, D. (2007). Body dissatisfaction and body comparison with media images in males and females. Body Image, 4(3), 257-268.

Vandenbosch, L., \& Eggermont, S. (2013). Sexualization of adolescent boys: Media exposure and boys' internalization of beauty ideals, self-objectification and body surveillance. Men and Masculinity, 16, 283-306.

Webb, H. J., \& Zimmer-Gembeck, M. J. (2014). The role of friends and peers in adolescent body dissatisfaction: A review and critique of 15 years of research. Journal of Research on Adolescence, 24(4), 564-590.

Xu, X., Mellor, D., Kiehne, M., McCabe, M., Ricciardelli, M., \& Xu, Y. (2010). Body dissatisfaction, engagement in body change behaviors and sociocultural influences on body image among Chinese adolescents. Body Image, 7, 156-164. 


\title{
PREDIKTORYTÚŽBY PO SVALOCHUADOLESCENTOV
}

\author{
J. Mustapic, D. M a r c ink o, P. Vargek
}

Súhrn: Ciel'om štúdie bolo skúmat' spokojnost' s vlastným telesným vzhl'adom, tlak vrstovníkov a hanbenie sa za telesný vzhl’ad ako prediktory túžby po svaloch u chlapcov adolescentov. Celkovo 213 adolescentov vyplnilo dotazníky hodnotiace spokojnost's vlastným telom, tlak vrstovníkov a hanbenie sa za telesný vzhl'ad a túžbu po svaloch. Výsledky ukázali, že túžba po svaloch bola predikovaná hanbením sa za telesný vzhl’ad a spokojnost’ou s vlastným telom. BMI, vek a prežívaný tlak vrstovníkov nezohrávali u respondentov žiadnu úlohu, t.j. neboli ako signifikantný prediktor túžby po svaloch. V budúcnosti by sa mal longitudinálny výskum zamerat' na objasnenie úlohy hanbenia sa za telesný vzhl’ad pri vzniku túžby po svaloch a extrémnom správaní meniacom telesnú stavbu. 